\title{
O PENSAMENTO CONSERVADOR IBERO-AMERICANO NA ERA DAS INDEPENDÊNCIAS (1808-1850)
}

Christian Edward Cyril Lynch

O conceito de conservadorismo possui uma conotação fortemente negativa na América Ibérica. O conservador é geralmente visto como alguém aferrado a uma visão hierárquica do mundo, defensora de privilégios, que vê com maus olhos a democratização, o reconhecimento dos direitos das minorias etc. Uma das explicações possíveis dessa conotação encontra-se no legado da tradição marxista, para a qual o conservadorismo era a ideologia das classes dominantes, ou seja, do establishment sociopolítico antipopular. O século XX brasileiro foi pródigo em produzir intelectuais nessa linha, como Caio Prado Jr., Nélson Werneck Sodré, e em menor medida, José Honório Rodrigues. Outra explicação plausível, e que não é incompatível com a anterior - embora não seja exclusiva dela - reside no próprio passado colonial dos países do continente e na persistência de suas mazelas socioeconômicas. Se o conservadorismo político necessariamente tem uma postura, senão simpática, ao menos respeitosa do passado, ele acaba afrontando a percepção, bastante difundida, de que os males crônicos do continente se enraízam nesse passado colonial, caracterizado pela exploração metropolitana, pelo patrimonialismo, pelo 
escravismo, pelo latifúndio. O passado, portanto, se erige em verdadeiro espantalho da nacionalidade, que precisa ser exorcizado e superado para que o país alcance aquele patamar de desenvolvimento compatível com um padrão civilizatório dos países centrais, como os Estados Unidos, a França e a Inglaterra. Aqui nos defrontamos com toda uma literatura política longeva de quase duzentos anos, que na Argentina gerou autores como Sarmiento e Alberdi, e no Brasil, Tavares Bastos, Manuel Bonfim e Raimundo Faoro ${ }^{1}$.

É justamente o sentido do que seja conservadorismo que gostaria de rediscutir aqui preliminarmente, a fim de reexaminar o papel por ele desempenhado na América Ibérica oitocentista - em especial, no tempo das chamadas revoluções atlânticas, isto é, a era das independências. Para fins de análise de discurso político, a identificação dos grupos políticos como sendo de esquerda ou de direita não deve ser feita apenas pelo exame de seu conteúdo ideológico. 60 Além de ser este demasiado subjetivo e mutável no tempo, a ignorância deste fato é aproveitada por movimentos políticos posteriores para reivindicar determinadas ideologias como suas ancestrais, no intuito de legitimar genealogicamente suas aspirações de poder, ainda que nada tenham de substantivo em comum². Seria mais apropriado compreender a esquerda e a direita a partir de seus lugares no espectro político, ou seja, como programas contrapostos que traduzem contrastes de interesses e valorações a respei-

\footnotetext{
${ }^{1}$ As próprias teorias ou ideologias do desenvolvimentismo das décadas de 1950 constituem seus consectários lógicos, encontrando suas melhores expressões nos autores da Cepal e aqueles por ela influenciados, como Octavio Ianni, Guerreiro Ramos e Fernando Henrique Cardoso (Valdés, 2000).

${ }^{2}$ Assim, a herança jacobina não foi apenas reivindicada pelos socialistas, mas também pelos bonapartistas - e por muito tempo, de forma mais eficaz. Outros exemplos óbvios podem ser extraídos da presente situação política, em que tanto o PT como o PSDB se apresentam como seguidores de JK; o PTB de Roberto Jefferson se apresenta como seguidor do "trabalhismo" de Getúlio Vargas - e isto, quando nada da prática política desses partidos indica qualquer fidelidade substantiva a tais personalidades históricas.
} 
to da direção a ser seguida pela sociedade. Enquanto lugares, direita e esquerda exprimem divergências inarredáveis por existirem em qualquer sociedade e que não têm como desaparecer (Bobbio, 1995, p. 33). Além disso, é preciso frisar que direita e esquerda são posições que decorrem da própria natureza antagônica da atividade política. Enquanto espaço do entrechoque e da polêmica entre contrários, a política exige de seus atores que se definam em relação uns aos outros para legitimar sua aspiração ao poder ${ }^{3}$. Pela adoção desse critério mais formal e intemporal, se torna possível identificar a presença de direitas e esquerdas desde o advento do sistema constitucional e representativo, na passagem do século XVIII para o XIX, e mesmo no interior de partidos ou regimes autoritários, conforme sejam mais ou menos extremistas ${ }^{4}$.

Tais considerações me parecem importantes na medida em que, para compreender as mutações e adaptações sofridas pelas ideologias conservadoras quando de sua aclimatação na América Ibérica, é preciso relativizar suas caracterizações enquanto tipos ideais elaborados na Europa. Duas referências metodológicas que orientam aqui. A primeira é do contextualismo lingüístico de John Pocock, cuja noção de ideologia, entendida como discurso político, se desdobra

\footnotetext{
${ }^{3}$ É a mesma lógica que leva uma esquerda a tornar-se centro ou direita quando surge uma posição ainda mais à esquerda que a sua, e/ou quando a antiga direita desaparece. Foi o que ocorreu, por exemplo, por volta de 1880 na França, quando o grupo legitimista se extinguiu, e o movimento socialista levou os liberais franceses a passarem para o centro ou para a direita do cenário político. Fenômeno semelhante ocorreu na Inglaterra, décadas depois, quando o lugar dos liberais foi tomado pelos trabalhistas.

${ }^{4}$ Curioso observar que, invariavelmente, a vertente mais moderada é acusada pela mais radical de conservadora. Assim, para Lênin, tudo o que estava à sua esquerda era conservador ou burguês - liberais democratas, monarquistas constitucionais, absolutistas etc. Entretanto, durante a Restauração, quando a direita era formada por nostálgicos do Antigo Regime, os liberais doutrinários, como Guizot, eram o centro; ao passo que um liberal puro como Benjamin Constant, que durante o século XX teria, entretanto, a pecha de conservador, encontrava-se à esquerda do espectro político.
} 
em três acepções (Pocock, 1985, p. 216): 1) Pensamento considerado como retórica ou discurso em ação; 2) Pensamento determinado e limitado - às vezes em tensão com - pelas formas de discurso disponíveis para sua expressão; 3) Uma visão de mundo determinada por vários fatores a que se pode atribuir terem-na determinado (que não se confunde com uma exclusiva teoria preconcebida, da qual pode, entretanto, ter sido derivada). A segunda referência é a da história dos conceitos de Reinhart Koselleck (Koselleck, 2006). Se o conceito do político exige a presença de uma esquerda e de uma direita, depreende-se naturalmente que as ideologias ou conceitos que orientam os atores políticos também se definam a partir da oposição recíproca, isto é, por aquilo que eles não são relativamente aos seus oponentes. Pretendo assim identificar, nos atos de fala dos atores envolvidos na luta política, a presença de conceitos e argumentos característicos de discursos elaborados alhures e compreender como a circuns-

62 tância, a necessidade e a contingência levaram tais atores a, na América Ibérica, lançarem mão de tais conceitos e eventualmente imprimir-lhes novos significados.

\section{0 discurso de reação: legitimismo republicano?}

Se o conceito oitocentista de conservadorismo era definido em oposição àquele de liberalismo, achando-se o primeiro à direita e o segundo à esquerda, buscarei me cingir às duas espécies de discursos antiliberais então existentes e que podem se enquadrar genericamente como direita conservadora: a do legitimismo e a do conservadorismo propriamente dito. Produto da emigração aristocrática, que começou poucos meses depois da instauração da conversão dos Estados Gerais em Assembléia Nacional na França, o legitimismo ou tradicionalismo é uma ideologia reacionária, porque contrária ao racionalismo dominante nas Luzes e que, como tal, negando a filosofia da história como progresso, pretendia retornar às matrizes organicistas e católicas 
do Antigo Regime. Quatro eram os objetivos do legitimismo: a adoção de um catolicismo integral e de uma cultura sociopolítica que não contrariasse os princípios da fé estatuídos pela igreja romana; a defesa do absolutismo monárquico e o restabelecimento da hierarquia social entre as três ordens. Embora genericamente considerado conservador, porque de direita, o discurso tradicionalista não constitui, todavia, uma ideologia de conservação, mas de reação ao movimento constitucionalista que já havia tomado o poder (Rémond, 1982).

Na França, a história do legitimismo como força política atuante começa propriamente em 1814, quando, com a restauração dos Bourbons, seus adeptos se organizaram num partido denominado ultra, isto é, ultramonárquico, que tinha duas principais correntes, a dos reacionários e a, como se dizia então, “de movimento”. Liderados por Chateaubriand, estes últimos se aproximavam dos liberais quando pleiteavam uma monarquia parlamentar à inglesa e a plenitude da liberdade individual, principalmente a de imprensa. No entanto, não foram eles que deram a tônica característica do legitimismo. Doutrinada por católicos extremados, como o Visconde de Bonald, reacionários como La Bourdonnaye sustentavam que a solução da crise revolucionária passava pelo retorno às fórmulas do governo misto medieval, na qual clero e nobreza se contraporiam ao Rei (Waresquiel e Yvert, 2002). Depois da Revolução de 1830, os legitimistas prosseguiriam sua campanha contra os Orléans e a ordem liberal, defendendo a restauração da dinastia legítima - os Bourbons - e os valores do Antigo Regime. Essa concepção de ordem cristã como natural e justa radicava na idéia de naturalidade da hierarquia e das diferenças entre os homens. Para Bonald, a monarquia tradicional era uma forma de governo que refletia a organização divina e, como tal, era necessária à preservação de uma sociedade cristã. Conferidos pela Providência como 
um benefício ou um castigo, os governos deveriam estar de acordo com as leis naturais da ordem social,

“cujo supremo legislador é o autor e o conservador, e o poder público assim considerado é tão de direito divino como o poder doméstico" (Bonald, 1988, p. 44).

Havia uma relação evidente entre a demanda de um governo constitucional e representativo e o surgimento de uma camada social nova em relação às antigas ordens estamentais do Antigo Regime, vinculada à sociedade urbana, ao comércio e às profissões liberais, ao comércio e à indústria, chamada desde então de burguesia. Foi o triunfo dela que obrigou os antigos detentores do poder, isto é, a nobreza e seus adeptos, a reaprender a cultura política do Antigo Regime para, apresentando-a como uma ideologia tradicionalista, reagir contra o liberalismo e desban64 cá-lo. Num quadro como este, o maior ou menor êxito da empreitada legitimista dependia diretamente do grau de desenvolvimento do novo setor produtivo e de sua capacidade de gerar novas representações capazes de prevalecer sobre aquelas do Antigo Regime junto aos setores mais relevantes da população de cada país. Por isso mesmo, o legitimismo encontrou fortíssimo eco em sociedades européias menos receptivas à cultura política liberal, como eram as da Península Ibérica, que não haviam vivenciado, de forma intensa como na França, nem as transformações ideológicas desencadeadas pelo Esclarecimento, nem as mudanças de natureza socioeconômica da primeira Revolução Industrial.

Na Espanha, o retorno de Fernando VII em 1814 ao poder e sua supressão da Constituição de Cádiz desencadearam uma luta encarniçada entre absolutistas e liberais. A Igreja principalmente teve um destacado papel nesse movimento de reação, qualificada como 
"uma cerração reacionária completa e uma perseguição - que muitas vezes superou os limites do sadismo - contra tudo o que soasse liberal" (Cierva, 1997, p. 610).

Interpretando a luta contra o liberalismo como uma luta contra o mal e o estrangeirismo, padres entre os quais Cádiz, Vélez e Alvarado, acusavam as sociedades secretas e os maçons de causadores dos males que assolavam o país, identificando o absolutismo católico com a autêntica tradição espanhola. Com sua doutrina de contrato social e direitos humanos, a filosofia moderna devolvia o homem a uma condição bestial na qual ele voltava a ser refém das paixões; os únicos direitos humanos possíveis eram aqueles presentes nos Evangelhos (Alonso, 2002). À posterior ascensão de sua esposa, Maria Cristina, à condição de regente, bem como ao pacto de governabilidade celebrado por ela com os liberais, outorgando uma nova Constituição - o Estatuto Real -, os legitimistas responderam com uma guerra civil. Negando que a herdeira da Coroa fosse filha do rei defunto, o príncipe Dom Carlos desencadeou a primeira das três guerras civis que devastaram o país durante aquele século - a primeira das quais, durou sete anos -, reivindicando a defesa da monarquia legítima e, com ela, a restauração dos princípios hierárquicos, tradicionais e católicos do Antigo Regime. O tradicionalismo encontrou campo fértil na Espanha, que produziu intelectuais de grande repercussão, críticos do liberalismo e da democracia na década de 1840, como Jaime Balmès, pragmático autor de Da força do poder na monarquia e Do catolicismo comparado ao protestantismo, em que a força do legitimismo vinha aliás algo mitigada, e o apocalíptico Donoso Cortès, Marquês de Valdegamas, liberal doutrinário renegado, e autor do impressionante Ensaio sobre o catolicismo, o liberalismo e o socialismo - provavelmente, a obra política espanhola mais influente do século XIX ${ }^{5}$.

\footnotetext{
${ }^{5}$ A derrubada da monarquia isabelina em 1868 e o advento do chamado sexênio
} 
Ainda que essa influência não se tenha feito sentir de modo substantivo antes de 1845, a influência do pensamento legitimista na América Espanhola foi bastante significativa - especialmente naqueles países onde houve maior resistência da Igreja à aceitação dos princípios liberais. $\mathrm{O}$ conflito entre Igreja e Estado descambou então numa guerra generalizada, especialmente no México e na Colômbia, ao passo que, pela primeira vez, a questão religiosa assumiu centralidade política no Equador, no Peru e no Chile (Safford, 2001, p. 383). Seja como for, à medida que, na América Ibérica, absolutismo era sinônimo de Antigo Regime, os pleitos pelo retorno à ordem tradicional assumiam conotações claramente recolonizadoras e antipatrióticas. Por esse motivo, o legitimismo católico teve de se adaptar às condições políticas do novo continente, aceitando o fato das independências, com a conseqüente adoção de monarquias constitucionais ou repúblicas, mas tentando insuflar, 66 o tanto quanto possível, o espírito do Antigo Regime nessas novas instituições. No Peru de 1837, José Maria de Pando já registrava em seus Pensamentos e notas sobre moral e política citações tanto de Bonald como de Maistre. Algumas décadas depois, Miguel Antonio Caro verberava na Colômbia contra a "liberdade liberal": "essa liberdade egoísta que se chama deusa e que quer para si a adoração somente devida a Cristo". Porque "a liberdade absoluta envolve a liberdade do mal", a absoluta liberdade de pensamento e de imprensa trazia consigo "a do vício, a loucura e o crime". Ao fazer do homem o único árbitro de sua própria sorte, o liberalismo separava o homem de Deus e levava ao despotismo (Romero, 1978, pp. 68-69). No Equador, o presidente Gabriel Gar-

democrático renovariam a literatura legitimista em autores como Navarro Villoslada e Aparasi y Guijarro que, como Donoso Cortès, já viam o socialismo como um perigo muito superior ao estéril liberalismo (Alonso, 2002). Por fim, na década de 1880, ainda haveria quem, como o padre Felix Sardà i Salvany, escreveria um livro célebre intitulado O liberalismo é pecado. 
cia Moreno declarava que o liberalismo era "a enfermidade endêmica do século”. A política laica do governo chileno era atacada por Joaquim Gandarillas, ao passo que Carlos Walker Martinez alardeava que o liberalismo era a forma pela qual, no século dezenove, o erro tomava forma. Já no Rio da Prata, José Manuel Estrada clamava que, para recuperar a justiça, era preciso que a República restaurasse

"o reinado social de Jesus Cristo e como instrumento e princípio de sua regeneração na fé e na moral, a constituição de um governo conservador e cristão. Deus é o manancial de toda a lei, o supremo ordenador da harmonia moral e o foco excelso de toda autoridade, porque de Deus vem e a Deus vai o homem que é naturalmente sociável em virtude de sua Providência infinitamente sábia. O poder público se constitui portanto para exercer o princípio de autoridade, que vem de Deus, conferindo aos imperantes, por meio da comunidade, o direito de governar o povo" (Romero, 1978, p. 263).

A irrupção do constitucionalismo em Portugal e a reação legitimista que se seguiu tiveram conseqüências semelhantes, embora menos ferozes do que as verificadas na Espanha, atravessando o país durante treze anos em períodos alternados de absolutismo e liberalismo. Inicialmente, travou-se uma luta na qual Dom João VI ziguezagueava de um pólo a outro, prensado entre seus conselheiros liberais, como o Duque de Palmela, e a camarilha absolutista liderada por sua esposa Carlota e seu filho Miguel. Com a morte do rei, Dom Pedro IV outorgou ao país uma constituição liberal, a que se seguiu um golpe absolutista promovido pelo irmão Miguel, que se fez coroar Rei. A expulsão do usurpador e a consolidação do liberalismo em Portugal a partir de 1833 não importaram, porém, no desaparecimento do discurso legitimista. Do ponto de vista doutrinário, 
ele continuou a corresponder ao núcleo fundamental do Partido Conservador daquele país, encontrando grande desenvolvimento teórico em autores como José da Gama e Castro que, em obras como $O$ novo príncipe, continuaram a defender o retorno ao Antigo Regime (Paim, 1998, p. 96). Segundo este autor, o progresso histórico não era retilíneo e antropológico, mas circular e providencial, motivo pelo qual o homem era incapaz de alterar o curso da história. Este curso, ele deveria aceitá-lo e segui-lo de modo ordeiro, respeitando as instituições vigentes. Cada sociedade teria o seu centro político, a sua constituição natural, correspondente à sua tradição e à sua autenticidade (Torgal, 1998).

No entanto, comparado ao mundo ibérico e mesmo ibero-americano, a influência do legitimismo no Brasil foi de uma moderação e fraqueza surpreendentes. A legitimidade do trono constitucional bragantino surgido com a independência; a impossibilidade de se pensar em retor68 no ao Antigo Regime sem implicar uma recolonização, e a inexistência de qualquer alternativa dinástica, isto é, de um príncipe disposto a bancar, no Brasil, o retorno ao absolutismo, limitaram severamente as possibilidades do discurso contra-revolucionário no Brasil, onde liberalismo era sinônimo de independência nacional.

Uma comparação entre o legitimismo brasileiro e o português exemplifica as limitações impostas pela realidade brasileira àquele discurso. Embora comungasse do mesmo universo teórico e se encontrasse sob o governo das mesmas instituições monárquico-constitucionais, o legitimismo adquiriu grande expressão em Portugal; lá, a luta da Igreja e do absolutismo contra os direitos fundamentais e o liberalismo levou, quando da vitória deste, a uma reação firme contra seus inimigos, separando-se a esfera secular da temporal e procedendo-se ao confisco da propriedade eclesiástica (Bonifácio, 2007). No Brasil, porém, a aliança do Estado com a Igreja havia sido preservada por meio de uma 
transação: os bens eclesiásticos seriam respeitados pelo Estado, mas a Igreja seguiria subordinada e aceitaria a liberdade religiosa e o regime representativo que tolerava os direitos fundamentais; de sorte que os potenciais legitimistas ou absolutistas se viram na contingência de aceitarem e defenderem a ordem constitucional inaugurada em 1824. Assim, se os legitimistas brasileiros se caracterizavam pela defesa da monarquia legítima, da união entre Estado e Igreja e da oposição ao casamento civil (Paim, 1998, p. 96), o simples enunciar desse programa evidencia seu baixo potencial de conflito no Brasil. Aqui, o Estado e a Igreja haviam mantido uma união formal, não havia projeto de casamento civil e, a despeito do liberalismo reinante, a dinastia legítima estava no trono - ao contrário do que ocorria na Espanha, em Portugal e na França, onde Dom Carlos, Dom Miguel e o Conde de Chambord estavam no exílio.

Uma única corrente legitimista parece ter adquirido alguma relevância - aquela dos irmãos Sousa - José Soriano, Tarquínio Bráulio e Brás Florentino - em Pernambuco. Uma única obra política de tintas legitimistas foi produzida por este último - Do poder moderador, defesa da autoridade do Imperador contra as pretensões parlamentaristas do Partido Progressista. Para Florentino, a religião era o suporte moral da política. Organizados à imagem do céu e da Igreja romana, os sistemas políticos dos países católicos precisavam de um poder último, soberano e absoluto, encarregado de manter a unidade e a hierarquia e, assim, superar os perigos da divisão de vontades, que era a "enfermidade orgânica dos corpos coletivos". O chefe do Estado era a cabeça do corpo político, constituindo "a autoridade diretorial e superior" (Florentino de Souza, 1978, pp. 43 e 51). A função representativa do Imperador era interpretada antes em chave hobbesiana que propriamente liberal. Ele não era mero mandatário da Nação; ele "resume o Estado em sua pessoa, é a constituição encarnada” (Florentino de Souza, 
1978, p. 56). No entanto, essa própria obra deixa entrever a dificuldade de se empregar argumentos como o do legitimismo, estranhos ao espaço loquacional do liberalismo na esfera política brasileira daquele tempo. Quando Florentino se vê na contingência de fazer a defesa institucional da Coroa, ele põe de lado o discurso contra-revolucionário dos legitimistas e recorre expedito ao liberalismo monarquiano, isto é, à ideologia conservadora então predominante no Brasil. Numa interessante inversão de prioridades, Florentino passava a combater as concepções institucionais do legitimismo bonaldiano e donosiano, que preconizavam a hereditariedade do pariato senatorial e a descentralização política, para fazer a defesa das instituições da Carta de 1824 (Lynch, 2007).

\section{O conservadorismo: discurso de resistência ou construção?}

Comparado ao legitimismo ou tradicionalismo, a principal

70 característica da ideologia conservadora propriamente dita foi a de constituir, não uma reação ao advento do governo constitucional e representativo, que ela apoiava, mas de resistência àquilo que ela julgava exagerado nas propostas do liberalismo de esquerda. Por liberalismo de esquerda, me refiro aqui ao racionalismo das Luzes francesas, politicamente calcado no jusnaturalismo contratualista, com sua otimista filosofia da história como progresso, que tomava o passado como sinônimo de trevas e propunha uma ruptura com a história pela via da razão. Nem por isso os conservadores estavam mais próximos dos legitimistas, com sua recusa radical às inovações e ao reconhecimento de que se viviam tempos modernos. No entanto, tão absurdo quanto defender a tese de que o poder decorria do direito divino, era sustentar que o único governo legítimo era aquele derivado da eleição popular (Burke, 1997, p. 64). A partir de uma concepção mais realista do que otimista do progresso e das possibilidades de preservação do tecido social, a ideolo- 
gia conservadora advogava uma visão política na qual a tradição, ao invés de aprisionar o presente num círculo perpétuo, pudesse ao menos guiar o progresso numa senda prudente e gradual, sem cair nos excessos das rupturas revolucionárias (Oakshott, 1981, p. 23). Ou seja, era a experiência histórica que deveria ajudar a organizar o presente, sem com ele se confundir. Neste sentido, ao menos como tipo ideal, o conservadorismo pode e deve ser interpretado como uma espécie de liberalismo - um liberalismo de direita.

Segundo Pocock (1987), a ideologia conservadora emerge do debate político travado na Inglaterra nas décadas de 1710 e 1720. De um lado, estavam os defensores de uma visão política tributária do republicanismo cívico, como Bolingbroke, para quem a ordem política legítima emanava de uma concepção estática da "Antiga Constituição", entendida como um governo misto a partir de uma concepção cíclica da história. De outro, estavam aqueles que, como Hume, sustentavam uma concepção evolucionária daquela carta, baseados numa filosofia progressiva da história, aberta, portanto, às mudanças exigidas pelos novos tempos. Para estes, as idéias não decorriam de uma razão abstrata, mas da experiência validada pela memória (Hume, 1985a, p. 142). Os hábitos, as tradições e os costumes - e não idéias abstratas - é que eram os responsáveis pela acomodação de valores decorrentes de paixões individuais. Sedimentadas no tempo de gerações, esses hábitos haviam se amalgamado numa cultura de valores comuns, no âmbito dos quais os indivíduos podiam se orientar na satisfação de suas paixões dentro, todavia, de regras de convivência que eram vantajosas para todos. Enquanto animal político, o homem não deveria, por amor à abstração, pôr em risco instituições que, a despeito de suas eventuais insuficiências, garantiam o equilíbrio social pela moderação recíproca de seus contrários, garantindo de facto os direitos, produzindo dirigentes de qualidade razoável e distribuindo a justiça de forma a 
garantir a ordem. Descartando a idéia de contrato social, Hume entendia que a obediência aos governos se originara de sua aceitação pela maioria e pela sua tolerância com as divergências sociais. Porque ambas eram essenciais à existência da sociedade e aos direitos civis, a tensão entre autoridade e liberdade era uma constante que não tinha como ser resolvida ${ }^{6}$; por isso, o direito de resistência ao governo somente se justificava quando o Parlamento não tivesse outro meio de se opor a um rei que pretendesse claramente extrapolar suas prerrogativas (Hume, 1985b, p. 245).

Nesse sentido, ao se chocar frontalmente com o republicanismo continental, racionalista e geométrico, cuja figura paradigmática era a do abade Sieyès, Burke pode ser visto como o autor em cuja obra a ideologia conservadora assumiu sua forma acabada. Burke reiteraria as premissas evolucionárias de Hume ao salientar que um Estado, privado de meios de se reformar, estava condenado a perecer (Burke, 72 1997, p. 61); no entanto, ele destacava que nem por isso a história deveria deixar de ser respeitada, devendo a ordem política alterar apenas de modo lento e gradual. Romper com a cadeia da continuidade histórica significava destruir uma cadeia ecológica integrada pelos vivos, pelos mortos e pelos nascituros. Era aí que residia a diferença principal

\footnotetext{
6 "Em todos os governos existe uma permanente luta intestina, aberta ou silenciosa, entre a Autoridade e a Liberdade, e nesse conflito nem uma nem outra pode jamais prevalecer de maneira absoluta. Em todos os governos se tem necessariamente que fazer um grande sacrifício da liberdade, e contudo também a autoridade, que limita a liberdade, jamais deve, em qualquer constituição, tornar-se completa e incontrolável [...]. O governo que, na linguagem vulgar, recebe a designação de livre, é aquele que permite uma divisão de poder entre vários membros, cuja autoridade conjunta não é superior à de qualquer monarca; mas esses membros, no curso normal da administração, devem agir de acordo com leis gerais e sempre idênticas, que são previamente conhecidas por todos os membros do governo e todos os súditos. Neste sentido, forçoso é reconhecer que a liberdade é a perfeição da sociedade civil, sem que isso permita, contudo, negar que a autoridade é essencial para sua própria existência; e por isso esta última pode merecer a preferência, nessas disputas em que tantas vezes uma é oposta à outra" (Hume, 1985b, p. 228).
} 
entre os liberais racionalistas e aqueles que viriam a ser denominados conservadores - a rejeição da idéia de ruptura que, para estes, desbaratava a vida social e a economia. Aceitando a noção de direitos individuais, os conservadores apenas lhes negavam o caráter abstrato e universal para afirmar sua particularidade conforme a cultura histórica concreta de cada sociedade. Desgarrados de seus respectivos contextos, conceitos abstratos como "justiça”, "razão", "direitos naturais" não passavam de uma sofística demagógica de ambiciosos imprevidentes. $\mathrm{O}$ conservadorismo passou a ser entendido então como a defesa de todos os princípios que colaborariam para a manutenção do tecido social e da sociabilidade, da família e dos valores cristãos - a ordem, a autoridade, os costumes e a tradição -, compatibilizandoos, porém, com a ordem econômica liberal e com o sistema representativo.

Na Europa continental, a forma canônica de conservadorismo será a do liberalismo doutrinário, cujo principal representante foi François Guizot. Tendo em vista o processo histórico da Inglaterra, até então na vanguarda do progresso histórico, os conservadores franceses interpretavam os eventos revolucionários de 1789 como equivalentes aos daquele país no século XVII. Por um lado, eles pretendiam perenizar os frutos liberais da Revolução, vendo na ascensão da burguesia a consolidação da civilização em sua forma moderna. Por outro, diferenciavam o conservadorismo francês do inglês por considerarem a Monarquia de Julho a síntese e a superação da Constituição Inglesa, ao equilibrarem liberalismo e democracia. Orientados por uma concepção capacitária do governo representativo, os conservadores franceses não viam com bons olhos a perspectiva de um processo de democratização que, para eles, poderia levar à queda da qualidade da função publica e à desestabilização política. A democracia deveria ser compreendida antes como uma forma social de igualdade civil do que como 
uma forma de igualdade política - o que justificava as restrições de direitos eleitorais às classes altas e médias (Rémond, 1982). Além disso, os conservadores franceses continuavam a reservar ao Estado um papel ativo de intervenção na vida nacional. Atraindo para si o que havia de mais notável em inteligência e luzes na sociedade, cabia-lhe chamar as capacidades ao pé de si para avançar, por meio delas, sobre o restante da sociedade, dirigindo-a conforme o interesse público esclarecido. À medida que ia buscar junto ao poder social os cidadãos mais capazes para o exercício do governo, o Estado se elevava à condição de verdadeiro governo dos espiritos, onde a sociedade se autogovernava por meio de sua própria elite (Rosanvallon, 1985, p. 279).

Entretanto, na época das revoluções atlânticas, a recepção do discurso conservador na América Ibérica enfrentava sérios problemas. O principal residia em apreender o que significava ser conservador em países novos, recém-inde74 pendentes, que decidiam romper com o passado colonial e selar um compromisso com o futuro na forma de projetos de construção de um Estado e de uma nação. Num contexto como este, a conservação poderia ser confundida com a defesa do Antigo Regime, ou pior, com a preservação do execrado estatuto colonial. Na verdade, como os liberais, os conservadores eram favoráveis ao governo constitucional e representativo e, como tais, se viam também diante do imperativo de construir uma ordem nova, fabricando constituições e as instituições representativas dela decorrentes, como assembléias, tribunais, secretarias de Estado. No entanto, eles temiam os excessos dos mais liberais radicais que, sob o influxo do constitucionalismo de Cádiz e do exemplo federalista e republicano norte-americano, sem levar em consideração as estruturas sociopolíticas das antigas capitanias e vice-reinados, acreditavam poder criar uma ordem inteiramente nova, a partir de princípios gerais abstratos. Valendo-se de argumentos de ordem sociológica, os 
conservadores tentaram inicialmente fórmulas de composição com a metrópole, que lhes permitissem autonomia no interior da monarquia ibérica para organizar um governo constitucional próprio, sem romper, por outro lado, o vínculo político formal com a Europa. No entanto, o expediente conciliatório falhou por conta do absolutismo intransigente de Fernando $\mathrm{VII}^{7}$.

O vazio deixado pela autoridade monárquica comprovou os temores conservadores hispânicos de que seus povos se achavam numa rota segura para a anarquia. Na medida em que as diversas juntas formadas para governar as capitanias e vice-reinados se revelaram incapazes de manter a ordem pública, falhara a tentativa de conciliar o princípio da soberania popular com a obediência formal ao Rei, enquanto este se encontrava cativo na França. Em Buenos Aires e no Chile, os grupos em disputa recorriam aos golpes de Estado, ao passo que irromperam guerras civis inter-regionais no Rio da Prata, em Nova Granada e na Venezuela, quando as juntas das respectivas capitais tentaram controlar as províncias. Por conta disso, se a primeira direita hispano-americana foi integrada por políticos contrários à independência ou ao sistema constitucional representativo, ela logo teve de ceder o lugar àqueles que, dotados de certo realismo ou pessimismo sociológico, temerosos da fragmentação política e social, afastaram-se dos extremos para engendrar um modelo institucional que fornecesse um novo mecanismo estabilizador da sociedade. Calcados num discurso baseado nas diferenças da sociedade iberoamericana face à Europa ocidental, esses conservadores defendiam a centralização do poder em torno do chefe de Estado e a constituição de uma aristocracia política institucionalmente respaldada para consolidar o futuro Estado nacional.

\footnotetext{
${ }^{7}$ Este era um expediente que já havia falhado quando das tratativas mantidas pelos norte-americanos com os ingleses, antes da guerra de independência das treze colônias, quando se tentou acomodar a teoria britânica da supremacia parlamentar com a reivindicação autonomista dos colonos (Bailyn, 2003 p. 202).
} 
A partir, portanto, da necessidade de constituição de um Estado forte, dois grupos conservadores, cada qual oriundo de um dos extremos políticos, caminharam para o centro, um em direção ao outro, sem, no entanto, se acertarem a respeito do formato institucional. Aqueles que evoluíam do legitimismo ou da união com a Espanha passaram a defender o estabelecimento de uma monarquia constitucional, julgada mais adequada, como regime, aos costumes e tradições da América Hispânica. Com a restauração da monarquia legítima na França, limitada por uma Carta, a Constituição inglesa entrava no apogeu de sua popularidade e, com ela, as noções de governo misto, de equilíbrio de poderes por meio de freios e contrapesos, como fórmulas de resguardo da liberdade sem prejuízo da autoridade. Desse modo, a autoridade monárquica seria restabelecida conforme a fórmula inglesa de 1688, isto é, pela preservação da monarquia com a substituição do Rei absoluto por 76 outro constitucional. A receita havia sido preconizada por Burke, para quem a Revolução Gloriosa havia sido uma bem sucedida tentativa de fazer valer a monarquia constitucional ao baixo custo de "um pequeno e temporário desvio na estrita ordem de uma sucessão hereditária regular" (Burke, 1997, p. 58).

Os movimentos em prol da monarquia constitucional foram ensaiados no Rio da Prata pelo General Belgrano e por San Martín. No Congresso de Tucumã, em 1816, Belgrano argumentou que a adoção de uma monarquia constitucional seria útil tanto política como diplomaticamente, diante da desordem americana e do novo clima político europeu decorrente do Congresso de Viena. San Martín manteve contatos com a Rainha de Portugal e do Brasil, Carlota Joaquina, aventando a possibilidade de deslocá-la do Rio de Janeiro para o Rio da Prata, onde seria proclamada regente. Tentativas semelhantes tiveram lugar no Chile, onde também se acreditava que a monarquia constitucional 
manteria a unidade e a estabilidade da antiga capitania. A preferência era por infantes da própria Coroa espanhola; todavia, diante das dificuldades postas por Fernando VII para a cessão de algum membro de sua família, passou-se a aceitar cabeças coroadas de outras dinastias. Ocorre que a França e a Inglaterra não se entendiam sobre um nome aceitável, quando esse consenso era necessário para o reconhecimento da independência. Essas dificuldades levaram os conservadores a ensaiar uma solução caseira. Na Nova Espanha tentou-se uma saída napoleônica, aclamando-se um plebeu - o criollo Itúrbide, herói da independência como Imperador, conferindo-lhe o título de Agostinho I. O problema é que Itúrbide estava longe de granjear a legitimidade de que Bonaparte gozara vinte anos antes na França; além disso, um monarca criollo não apresentava qualquer tradição dinástica que legitimasse sua pretensão de exercer um papel de arbitragem ou de neutralidade sobre os demais caudilhos mexicanos. Esse problema também foi enfrentado no Rio da Prata por Belgrano, que propôs a entronização de um descendente dos incas. No seu caso, porém, a aristocracia criolla rejeitou a sugestão, porque desprezava os índios (Safford, 2001, p. 344) ${ }^{8}$.

Se muitos dos monarquistas constitucionais eram antigos absolutistas que haviam caminhado para o centro, o segundo grupo de conservadores era formado por antigos republicanos radicais, que haviam se desapontado com a experiência caótica que se seguiu à emancipação das anti-

\footnotetext{
${ }^{8}$ A idéia monárquica permaneceria no horizonte da América hispânica até pelo menos meados da década de 1860. Basta lembrar a ascensão de Maximiliano de Habsburgo ao trono do México, apoiado maciçamente pelo Partido Conservador daquele país. Na mesma época, desesperado da causa republicana, Alberdi cogitou da instauração de uma monarquia centralizadora na Argentina, que tivesse o Segundo Império francês por referência. "O Império", escrevia ele então, "não é a reação da revolução; é a maneira revolucionária de conciliar a ordem com a liberdade revolucionária, quer dizer, com a liberdade não experimentada, que se educa, e que é violenta pela falta de maturidade. É o governo revolucionário, como remédio à liberdade revolucionária” (Botana, 2005, p. 398).
} 
gas colônias hispânicas (e isto, a despeito das tentativas de estabilizar a sociedade pelo exercício de ditaduras provisórias, como foram as de O’Higgins e Bolívar). Embora esses neoconservadores se sentissem incapazes de abjurar suas antigas convicções republicanas, eles haviam perdido o otimismo universalista e racionalista das luzes francesas, expresso nos ideais de Sieyès ou no federalismo norteamericano. Em seu lugar, estava o que havia de mais pessimista no republicanismo de Rousseau: a descrença na possibilidade da democracia, governo próprio para anjos; a decadência cívica provocada pela modernidade do luxo, que corrompera a virtude e a substituíra pelo egoísmo; a ignorância de uma humanidade abandonada por suas elites inescrupulosas (Rousseau, 1997). Nesse contexto, a exemplo do que se dava com os monarquistas, a autoridade de Montesquieu passava a ser invocada pelos republicanos com mais constância, especialmente as passagens do Espírito das 78 Leis que exprimiam, de um lado, a dificuldade de implantar a república num país de grandes proporções; e, de outro, a maior conveniência de um regime autoritário em nações marcadas por grandes desigualdades de costumes. Era a mística da Constituição Inglesa que, mais uma vez, acenava com a possibilidade de resolver o problema, aparentemente insolúvel, da conciliação entre ordem com a liberdade (Montesquieu, 1979). Por fim, os republicanos conservadores sentiam-se atraídos pela recordação de Bonaparte como cônsul da República Francesa. Napoleão encarnava o ideal de uma república forte, cujos poderes deveriam se concentrar nas mãos de um chefe de Estado militar que, pela sua energia e virtude, garantisse a coesão das Forças Armadas e a obediência dos cidadãos.

O representante por excelência desse republicanismo conservador foi Simon Bolívar que, patriota, modesto, pessimista, se apresentava como perfeita encarnação do legislador ou do ditador rousseauniano. Embora reafirmasse 
sua antipatia pela monarquia, Bolívar reconhecia a situação extraordinária dos povos americanos emancipados do domínio político espanhol no Discurso de Angostura. Mantido sob o jugo do vício e da tirania, na completa ignorância do que fosse a virtude, sem a qual não tinha como vingar a república democrática, o povo sul-americano estava despreparado para a liberdade. A excelência de um governo não estava na sua teoria, mas "no fato de ser apropriado à natureza e ao caráter da Nação a que ele se dirige”. O caráter culturalmente híbrido e moralmente inferior do povo, desprovido de luzes, estava a exigir, não a debilidade de uma democracia, mas um governo forte e, como tal, capaz de lidar com uma sociedade que ainda não estava sedimentada. Depois de reconhecer a grande estabilidade dos governos aristocráticos e monárquicos, Bolívar elogiava a Constituição Inglesa: ela estava "destinada a operar o maior bem possível aos povos que a adotam" (Bolívar, 1983, pp. 250-251). A adaptação necessária da Constituição inglesa ao governo republicano passava, segundo ele, pela adoção de um senado hereditário, capaz de estabilizar as instituições e garantir a ordem, e por uma presidência forte, capaz de preservar a unidade do Estado naquele momento em que a Venezuela se achava na sua infância nacional. Ele sugeria ainda a criação de um quarto poder - um Poder Moral, composto por um tribunal de censores, que capacitasse o povo em longo prazo para agir de modo virtuoso ${ }^{9}$. Posteriormente, ao endereçar projetos constitucionais para a Bolívia e a Colômbia, mais desesperado da possibilidade de ordem, Bolívar radicalizaria suas propostas constitucionais, apostando na instauração

\footnotetext{
${ }^{9}$ Em suma, a pragmática Constituição equilibrada de Montesquieu era mobilizada para manter o Estado até que, pela ação do Poder Moral, fosse possível instaurar a virtuosa república rousseauniana. Ao defender uma Constituição unitária, que conferisse amplos poderes ao Chefe do Estado, Bolívar imaginava agir como Rousseau, que nas Considerações sobre o governo da Polônia deixara um exemplo de que o ideal republicano do Contrato social deveria se adaptar às realidades de cada sociedade (Rousseau, 1982).
} 
de constituições calcadas no modelo da república consular francesa.

De pouco adiantaram, porém, suas considerações sociológicas. As constituições bolivarianas duraram pouco e, no caso da Colômbia, a resistência da aristocracia foi de tal ordem, que Bolívar foi obrigado a recorrer a uma ditadura que quase lhe custou a vida num atentado. Com o fracasso do modelo bolivariano de república monárquica, os conservadores tiveram de recorrer seguidamente a outras duas instituições tradicionais, o Exército e à Igreja, para forjar um centro estabilizador à política. O resultado foi a politização de ambas as corporações, de que o anárquico México do General Santa Anna foi o mais eloqüente exemplo. Não por acaso, foi lá que o Partido Conservador continuou monárquico e simpático às posições legitimistas defendidas pela Igreja(Safford, 2001). As aristocracias agrárias ibero-americanas rejeitavam os modelos conservadores, porque lhes 80 pareciam demasiado monárquicos, ou seja, porque ameaçava criar um poder que elas não pudessem controlar; nesta mesma chave, temiam que, enquanto burocracia autônoma do Estado, o Exército acabasse por monopolizar a presidência, deixando-as alijadas do processo decisório.

No entanto, a resistência dos liberais hispânicos ao ideal de uma república forte e centralizada tendeu a se arrefecer no decorrer do século, quando a crônica instabilidade política os forçou a dar alguns passos à direita. Por um lado, dada a necessidade de organizar o Estado inexistente e, por conseguinte, de obter a submissão dos cidadãos a uma mesma autoridade comum, o excesso de liberdade na América Ibérica parecia-lhes agora de fato importar no enfraquecimento da autoridade e no favorecimento do caudilhismo - em suma, na anarquia. Por outro lado, o excesso de autoridade poderia implicar o retorno ao Antigo Regime ou de uma ordem análoga, o que também não era desejável. Daí que, em meados do século, surgiu a oportunidade para uma pax aristocrática 
entre as famílias liberais e conservadoras nos países onde era menor a divergência política, e a querela entre ambas adquiriu a possibilidade de alguma institucionalização. Na Argentina, o regime republicano chileno, teorizado por Egaña e implantado por Montt e Portales, centralista e aristocrático, com poderosos presidentes de longos mandatos e Congressos obedientes, tornou-se a república dos sonhos de Alberdi e Sarmiento. Elogiado pelo conservador chileno Andrés Bello, será este o modelo que os dois liberais argentinos proporão para o seu próprio país em 1853 - uma república que privilegiava a ordem antes da liberdade, por ver na primeira a condição de realizar a segunda. O mecanismo central de estabilidade do regime, neste modelo, residia na possibilidade de se suspender a Constituição por meio do instituto estado de sítio; possibilidade necessária, segundo Sarmiento, para organizar "um governo absolutamente livre, e fortíssimo por exceção" (apud Botana, 2005, p. 362).

\section{0 conservadorismo brasileiro e o Poder Moderador}

É dentro deste quadro geral dos dilemas do conservadorismo ibero-americano que deve ser considerada a posição da direita brasileira na época da independência. De saída, porém, saltam aos olhos algumas peculiaridades do processo de independência do Brasil. Em primeiro lugar, a colonização portuguesa revelou maior centralização política que a espanhola: enquanto o Império Espanhol estava dividido em diversas capitanias e vice-reinados autônomos, cada qual com sua respectiva capital, as vinte capitanias brasileiras estavam subordinadas a um único Vice-Rei instalado na capital geral da colônia - o Rio de Janeiro. Ainda que essa subordinação fosse, em larga medida, meramente nominal, o Vice-Rei detinha autoridade real pelo menos sobre as capitanias do sul - Rio de Janeiro, São Paulo, Minas Gerais, Espírito Santo, Santa Catarina e Rio Grande do Sul (Holanda, 1985). A segunda diferença reside no fato de o Brasil 
não ter experimentado de modo duradouro o vácuo de poder decorrente do encarceramento da Família Real espanhola por Napoleão Bonaparte. Muito pelo contrário, a decisão da Coroa portuguesa de se transferir para o Rio por ocasião da invasão napoleônica interiorizou a metrópole no Brasil (Dias, 2005). Há que se recordar, ainda, o fato de que todas as zonas populosas e economicamente relevantes da colônia (com a possível exceção de Minas Gerais) estavam na costa ou próximos dela, o que facilitava a repressão das tentativas de secessão por mar. Por fim, depois do retorno da Corte para Lisboa: a permanência do príncipe regente no Brasil viabilizou a independência por meio de uma monarquia constitucional autônoma e centralizada. Foi possível assim ao Brasil desligar-se do Antigo Regime e inaugurar um governo constitucional e representativo, preservando a principal instituição política do período colonial - uma Coroa imparcial e superior às grandes famílias aristocráticas, no centro de um território imenso e 82 despovoado, denominado justamente por isso de Império.

Além disso, o fato de a Coroa ter o apoio da burocracia do Estado, mas não ser possuidora de terras próprias, determinou sua relativa independência frente à aristocracia, permitindolhe um potencial mais propositivo e reformista do que seus equivalentes no continente (Carvalho, 1996). Não por acaso, foi na reflexão dos conselheiros de Estado do novo Imperador, Dom Pedro I, que o discurso conservador de Bolívar encontrou seu equivalente monárquico, no Brasil. Era um reformismo ministerialista inspirado no despotismo esclarecido que orientava então os diversos membros da alta burocracia luso-brasileira. Embora suas propostas reformistas não tenham obtido receptividade de Dom João VI, no Brasil foram estes reformistas quem se dedicaram à formulação de um projeto de governo constitucional e representativo no qual o príncipe - e não a assembléia - figurasse como o principal representante da soberania nacional. Dentre os estilos de liberalismo disponíveis - o republicano norte-americano, à Madison; o 
monarquiano de Malouet e Mounier, o racionalista de ideólogos como Sieyès e Destutt de Tracy; o liberal à Stäel e Constant - o monarquiano era aquele que melhor correspondia às preferências da alta burocracia brasileira, na medida em que transportava o ideal modernizador ordeiro do despotismo esclarecido para o quadro do sistema constitucional.

Embora admitisse a soberania nacional como princípio de legitimidade da ordem política, os monarquianos franceses - entre os quais Malouet, Mounier, Lally-Tollendal e ClermontTonnerre - haviam se negado desde o início da Revolução a associá-la à incontrastável supremacia de um poder legislativo unicameral, preferindo um Estado onde coubesse à Coroa o papel de guardiã dos interesses nacionais. Foi precisamente a defesa do veto absoluto do Rei que deixou transparecer o lugar de centralidade da Coroa dentro do Estado constitucional monarquiano. Era o Rei, sensível à opinião pública, quem poderia melhor interpretar seus sentimentos e defender a Constituição contra as invasões dos demais poderes, convertendo-se numa "poderosa barreira ao pé da qual se reunirão todos os verdadeiros amigos da ordem e da liberdade" (Mounier, 1996, p. 401 $)^{10}$. As prerrogativas monárquicas de veto legislativo e de dissolução da câmara baixa eram formas de apelo ao povo soberano, sem as quais não, segundo Lally-Tollendal, haveria

“obstáculo insuperável às investidas do poder legislativo contra o poder executivo, à invasão, à confusão dos poderes, por conseguinte à derrubada da constituição e à opressão do povo" (Bredin, 1988, p. 203) ${ }^{11}$.

\footnotetext{
${ }^{10}$ Ele era "o representante perpétuo do povo", cuja prerrogativa era essencial para se evitar que a nascente classe política, surgida da representação eletiva, acabasse por constituir uma nova aristocracia; era o único, dentre os poderes constituídos, capaz de "manter o equilíbrio e impedir as parcialidades", tendo, nos momentos de crise, força e prestígio suficientes para "reunir todas as partes e voltar aquela atividade para um centro comum" (Mirabeau, 1996, p. 370).

${ }^{11}$ Nessa categoria de principal intérprete do bem comum, Malouet chegaria ao
} 
Os monarquianos se revelaram herdeiros do reformismo ministerialista de Turgot, sem que seu discurso pudesse, entretanto, ser incluído na categoria do absolutismo ao transplantarem para o Estado de Direito a tese de

"um poder monárquico reforçado, capaz de representar a nação como um todo e inteira, às expensas das pretensões da assembléia de querer encarnar a soberania nacional" (Griffiths, 1988, p. 87).

Tanto assim, que as formas institucionais por eles advogadas eram compatíveis com a descrição que trinta anos antes Montesquieu fizera do governo inglês. Os monarquianos puderam assim, ao mesmo tempo em que acenavam com os argumentos mecanicistas e equilibrados da Constituição Inglesa, sustentar uma concepção constitucional ancorada numa Coroa forte.

84 No Brasil de 1823, os objetivos políticos da chamada "elite coimbrã" (Carvalho, 1996), isto é, da alta burocracia reunida em torno da Coroa - eram similares aos dos monarquianos de 1789: impedir o regime de assembléia única, cuja pretensão de preponderância era justificada por sua qualidade de depositária exclusiva da soberania nacional. Adotado na França (1791) e depois reproduzido na Espanha (1812) e em Portugal (1822), esse modelo sempre teria fracassado com resultados desastrosos para a ordem pública; daí que, na Constituinte do Brasil independente, preferiram sustentar um projeto caracterizado por uma Coroa forte políticos como José Bonifácio de Andrada e Silva, Antônio Carlos de Andrada Machado, Severiano Maciel da Costa, José Joaquim Carneiro de Campos e José da Silva Lisboa. Eles mobilizaram argumentos diferentes dos de seus 
adversários - os integrantes da chamada "elite brasiliense" (Neves, 2003), que gravitava em torno de Gonçalves Ledo e Januário da Cunha Barbosa. O projeto dos coimbrões se caracterizava por ser mais centralizador do que federativo; mais monárquico do que parlamentar e mais estatizante do que o dos brasilienses. Por outro lado, dada a sua maior proximidade da Coroa, o menor peso dos interesses particulares na visão de mundo estatocêntrica dos coimbrões lhes conferia maior sensibilidade quanto a temas estratégicos da construção do novo Império, o que se refletia na conveniência de abolir o tráfico de escravos e induzir a imigração européia. Esse não era o caso da elite brasiliense, mais representativa dos interesses da lavoura e que, entendendo mais rentável a continuidade pura e simples do sistema escravocrata, passou a temer medidas que acabassem por comprometê-lo (Lynch, 2005).

O projeto coimbrão encontrou seu maior expoente num antigo discípulo do Conde de Linhares, líder do reformismo ministerialista português - o agora deputado e ministro do Reino José Bonifácio de Andrada e Silva ${ }^{12}$. Para ele, dadas a vastidão de seu território e as inumeráveis riquezas nele disponíveis, as oportunidades oferecidas pelo novo Império eram ilimitadas; no entanto, dividida horizontalmente pelas distâncias e verticalmente pela escravidão, a própria nação ainda estava por fazer. Daí que era preciso abrir estradas, atrair a imigração estrangeira, desenvolver a agricultura, civilizar os índios, distribuir terras - enfim, lançar as bases de uma nação próspera e poderosa. Entretanto, a conjuntura no início da década de 1820 apresentava dificuldades a esse projeto, com suas graves divisões den-

\footnotetext{
${ }^{12}$ Sua filiação à tradição do despotismo ilustrado, filtrada pelo liberalismo monarquiano, fica explícita quando, depois de fazer o elogio de autocratas como Pedro, o Grande, e Frederico da Prússia, ele recomendava como adequadas às características do Brasil as instituições do governo misto ou da monarquia temperada que ele associava à Inglaterra (Andrada e Silva, 1998, pp. 174 e 247).
} 
tro e fora do corpo político. O papel civilizador da monarquia somente poderia cumprir seu destino caso estadistas ilustrados, fortes e hábeis afastassem semelhantes perigos (Andrada e Silva, 1998, p. 239). Foi nesse contexto de perigos à construção nacional que o projeto político coimbrão veio, por afinidade e contingência, se exprimir na linguagem constitucional dos monarquianos franceses, com a vantagem adicional de se poder, em 1823, explorar os fracassos dos modelos subseqüentes de monarquia republicana (1791) e de república jacobina (1793). Foi o que fez Pedro I na Fala do Trono com que abriu os trabalhos da Constituinte. Aqueles dois modelos de monarquia republicana eram "inteiramente teoréticos e inexeqüíveis", levando à "anarquia de muitos" e, depois, ao "despotismo de um só". As convulsões francesas, espanholas e hispano-americanas comprovavam que apenas um sistema constitucional realis$t a$, calcado na razão e na experiência, poderia viabilizar o 86 novo império (AACB, 1823, vol. I, p. 16) ${ }^{13}$.

Entre a monarquia republicana de Sieyès e a república monárquica de Bolívar, portanto, aquilo de que o Brasil carecia era de uma monarquia constitucional ou temperada, ou seja, um verdadeiro governo misto. A instituição que lhe serviria de centro estabilizador e permitira a expansão segura do Estado seria o Poder Moderador do monarca, entendido por seu principal teórico, José Joaquim Carneiro de Campos,

\footnotetext{
${ }^{13}$ Com referência a essa passagem da Fala do Trono, discursou José Bonifácio no dia seguinte: "Não acho nas palavras do Imperador senão nossas próprias e as da vontade geral do leal povo do Brasil. O que quer esse povo? E para que tem trabalhado o governo de forma tão dura? Para centralizar a união e prevenir a anarquia [...]. O povo brasileiro, Senhor Presidente, quer uma constituição, mas não quer demagogia e anarquia [...]. Que quadro nos apresenta a infeliz América! Há 14 anos seus povos se dilaceram; povos que, tendo saído de um governo monárquico, quiseram estabelecer uma licenciosa liberdade; povos que, depois de terem nadado em sangue, não são senão vítimas da desordem, da pobreza e da miséria [...] Vimos os horrores da França; suas constituições feitas para serem logo destruídas. Enfim um Bourbon, que os franceses haviam excluído do trono e mesmo execrado, veio para trazer-lhes a paz e a concórdia” (AACB, 1823, vol. I, p. 26).
} 
futuro Marquês de Caravelas, como um poder de exceção a serviço da salvaguarda do sistema constitucional. Havia sido a sistematização das antigas reflexões sobre o poder moderador por teóricos contemporâneos da monarquia constitucional, como Benjamin Constant, que lograra resolver aquele que, para Caravelas, era o problema central da política moderna: forjar uma ordem institucional capaz de equilibrar as justas aspirações à liberdade, materializadas no reconhecimento dos direitos fundamentais dos cidadãos e da esfera social e a necessidade de ordem, materializada na preservação da segurança pela autoridade pública no âmbito do Estado. Era da desconsideração desse imperativo que derivavam todas as revoluções por que o mundo europeu e americano atravessava desde o final do século anterior. Segundo Caravelas, enquanto governo misto, a monarquia constitucional deveria apresentar duas características que garantiriam o equilíbrio entre as suas partes. A primeira delas residia na integração do monarca no processo legislativo, podendo vetar os projetos de leis que julgasse formal ou materialmente nocivos à causa pública. Seguindo aqui a orientação dos monarquianos franceses (Lynch, 2005), Carneiro de Campos julgava esta prerrogativa essencial na medida em que conferia ao chefe da Nação o papel de guardião da Constituição, preservando-a contra as tendências da assembléia de expandir seus poderes a ponto de extrapolar suas competências legislativas.

A segunda característica da monarquia constitucional estava, ao revés, na possibilidade de

“os representantes da Nação, em quem muito principalmente reside o Poder Legislativo, concorram com o monarca na criação da lei, e modifiquem ou temperem a autoridade do monarca" (AACB, 1823) ${ }^{14}$.

\footnotetext{
${ }^{14} \mathrm{E}$ arrematava: "O que verdadeiramente caracteriza o governo monárquico representativo, e o distingue das repúblicas, é a grande influência que o monarca tem no corpo legislativo. Todos aqueles magistrados não eram monarcas, apesar
} 
Ora, essa faculdade de dispor do direito de veto na produção legislativa e de dissolução da Câmara fazia parte das atribuições que cabiam ao monarca, na qualidade de chefe supremo da Nação. Na qualidade de competências do Poder Moderador, eram elas que permitiam ao monarca garantir o equilíbrio do governo misto; existindo, como tal, de forma expressa ou velada, em todas as monarquias representativas. Como se percebe, o Poder Moderador de Carneiro de Campos era o direito que tinha a Nação de ser protegida pelo representante do bem comum quando estivesse desprovida de meios de autodefesa contra o particularismo dos interesses legislativos; a autoridade neutra capaz de manter in extremis a ordem constitucional contra as veleidades facciosas e particularistas de seus representantes eleitos. Não sendo possível que o povo soberano agisse por conta própria para fazer valer seus interesses, o fato de o governo ser representativo impunha a existência e a delegação daque88 le poder que, "como atalaia da liberdade e dos direitos do povo, inspeciona e equilibra todos os outros poderes" (AACB, 1823).

O Poder Moderador era, portanto, um poder discricionário exercido emergencialmente pelo chefe do Executivo para salvar o regime representativo nascente do perigo de desagregação do corpo político; uma espécie de freio de mão leviatânico para as emergências de um Estado constitucional incipiente e frágil, despido de tradições e por isso ameaçado por seu próprio déficit de legitimidade - um sucedâneo aperfeiçoado da ditadura romana descrita por Maquiavel.

O projeto constitucional dos coimbrões viria a prevalecer na Carta de 1824, que consagrava um Estado semiautônomo ao enfeixar os poderes moderador e executivo 
nas mãos do Imperador, assessorado por um conselho de Estado por ele escolhido, e consagrando um senado vitalício. Inicialmente hostil a esse modelo, a aristocracia rural lhe proclamaria adesão quinze anos depois, na medida em que a porção vitalícia do Estado se comprometesse a não atacar o regime de trabalho escravocrata. A alternância arbitrada dos partidos no governo foi facilitada então pelo surgimento de dois partidos bem definidos, que concordavam que o bipartidarismo era necessário para exprimir a luta eterna entre a ordem e a liberdade (Lynch, 2007). A conseqüência da consistência institucional adquirida pela política foi a renúncia dos partidos às armas ou à revolução. Neste sentido, os conservadores brasileiros cedo conseguiram aquilo que seus congêneres ibero-americanos continuaram a perseguir em vão: a ordem necessária para veicular o progresso sonhado pelos liberais. $\mathrm{O}$ fato de que a ordem só era possível na medida em que se conseguisse controlar os setores subalternos e excluídos da sociedade, e que por isso ela só poderia proporcionar liberdade àqueles que a comandavam de cima, era um problema a ser enfrentado num segundo momento. No entanto, os eventos posteriores demonstrariam que o desafio de conjugar a ordem com a expansão da liberdade, para além do círculo senhorial da América Ibérica, constituía tarefa mais complicada que fundar a autoridade.

\section{Christian Edward Cyril Lynch}

é professor do Programa de Pós-graduação em Sociologia e Direito da Universidade Federal Fluminense (UFF) e pesquisador da Fundação Casa de Rui Barbosa (FCRB)

\section{Obras citadas}

AACB, 1823. Anais da Assembléia Constituinte Brasileira.

ALONSO, C. L. 2002. "El pensamiento conservador español en el siglo XIX: de Càdiz a la restauración”. In: VALLESPÍN, Fernando (ed.). 
Historia de la teoría política. Vol. V: Rechazo e desconfianza en el proyecto ilustrado. Madrid: Alianza Editorial.

ANDRADA E SILVA, J. B. 1998. In: DOHLNJKOFF, M. (org.). Projetos para o Brasil. São Paulo: Companhia das Letras.

BAILYN, B. 2003. As origens ideológicas da revolução americana. Tradução de Cleide Rapucci. Bauru, SP: Edusc.

BETHELL, L. (orgs.). 2001. História da América Latina. Vol. III: Da Independência a 1870. Tradução Maria Clara Cescato. São Paulo: Edusc.

BOBBIO, N. 1995. Direita e esquerda - Razões e significados de uma distinção política. São Paulo: Unesp.

BOLÍVAR, S. 1983. Los projectos constitucionales del Libertador. Caracas: Congresso da República.

BONALD, L. 1988. Réflexions sur la Révolution de Juillet 1830 et autres inedits. Apresentação e notas de Jean Bastier. Paris: Duc Albatroz.

BONIFÁCIO, M. F. 2007. O século XIX português. $3^{\mathrm{a}}$ ed. Lisboa: ICS Imprensa de Ciências Sociais.

BOTANA, N. R. 2005. La tradición republicana: Alberdi, Sarmiento y las ideas políticas de su tiempo. $3^{\mathrm{a}}$ ed. Buenos Aires: De Bolsillo.

BREDIN, Jean-Denis. 1988. Sièyes - La clé de la Reévolution Française. Paris: Éditions de Fallois.

90 BURKE, E. 1997. Reflexões sobre a Revolução em França. $2^{\mathrm{a}}$ ed. Introdução de Conor Cruise O’Brien. Tradução de Renato de Assunção Faria, Denis Fontes de Souza Pinto e Carmem Lidia Richter Ribeiro Moura. Brasília: Ed. UnB.

CARVALHO, J. M. 1996. A construção da ordem: a elite política imperial; Teatro de sombras: a política imperial. $2^{\mathrm{a}}$ ed. rev. Rio de Janeiro: Ed. UFRJ/ Relume Dumará.

CIERVA, R. 1997. História total de Espanha: del hombre de Altamira al rey Juan Carlos. Madrid: Fênix.

CRESPIGNY, A. de; CRONIN, J. (eds.). 1981. Ideologias políticas. Tradução de Sérgio Duarte. Brasilia: Ed. UNB.

DIAS, M. O. L. S. 2005. "A interiorização da metrópole”. In: A interiorização da metrópole e outros estudos. São Paulo: Alameda.

DOHLNIKOFF, M. (org.). 1988. Projetos para o Brasil. São Paulo: Companhia das Letras.

FLORENTINO DE SOUSA, B. 1978. Do Poder Moderador: ensaio constitucional contendo a análise do Título V, Capítulo I, da Constituição Política do Brasil. Brasília: Senado Federal.

FURET, F.; HALÉVI, R. 1996. La monarchie republicaine - La Constituion de 1791. Paris: Fayard: 
GRIFFITHS, R. 1988. Le centre perdu: Malouet et les monarchiens dans la Révolution Française. Grenoble: Presses Universitaires de Grenoble.

HOLANDA, S. B. 1985. "A herança colonial - Sua desagregação”. In: História geral da civilização brasileira. Tomo II: O Brasil monárquico. Vol. I: O processo de emancipação. $6^{\mathrm{a}}$ ed. São Paulo: Difel.

HUME, D. 1985a. Investigação sobre o entendimento humano. Tradução de Leonel Vallandro. São Paulo: Abril.

1985b. Ensaios morais, políticos e literários. Tradução de João Paulo Gomes Monteiro e Armando Mora D’Oliveira. São Paulo: Abril Cultural.

KOSELLECK, R. 2006. Futuro passado: contribuição à semântica dos tempos históricos. Rio de Janeiro: Contraponto.

LYNCH, C. E. C. 2005. O discurso político monarquiano e a recepção do conceito de Poder Moderador no Brasil (1822-1824). Rio de Janeiro, vol. 48, $\mathrm{n}^{\circ} 3$, pp. 611-654.

2007. O momento monarquiano: o conceito de Poder Moderador e o debate político brasileiro do século XIX. Tese de doutorado. Rio de Janeiro: IUPERJ.

MALOUET, P.-V. 1996. "Discours de Malouet sur la sanction royale”. In: FURET, F; HALÉVI, R. La monarchie républicaine - La Constitution de 1791. Paris: Fayard.

MIRABEAU, H. G. R., Marquês de. 1996. "Discours de Mirabeau sur le droit de veto”. In: FURET, F; HALÉVI, R. La monarchie républicaine - La Constitution de 1791. Paris: Fayard.

MONTESQUIEU, C.-L. S., Barão de la Brède et de. 1979. Do espírito das leis. Introdução e notas de Gonzague Truc. Tradução de Fernando Henrique Cardoso e Leôncio Martins Rodrigues. São Paulo: Abril Cultural.

MOUNIER, J.-J. 1996. "Discours de Mounier sur la sanction royale”. In: FURET, F; HALÉVI, R. La monarchie républicaine - La Constitution de 1791. Paris: Fayard.

NEVES, L. M. B. P. 2003. Corcundas e constitucionais: a cultura política da independência (1820-1822). Rio de Janeiro: Revan.

OAKSHOTT, M. 1981. "Conservadorismo”. In: CRESPIGNY, A. de; CRONIN, J. (eds.). Ideologias políticas. Tradução de Sérgio Duarte. Brasília: Ed. UNB.

PAIM, A. 1998. História do liberalismo brasileiro. São Paulo: Mandarim.

POCOCK, J. G. A. 1985. Virtue, commerce and history: essays on political thought and history, chiefly in the eighteenth century. Cambridge: Cambridge University Press. 
1987. The ancient Constitution and the feudal law: a study of the English historical thought in the seventeenth century. A reissue with a retrospect. Cambridge: Cambridge University Press.

ROSANVALLON, P. 1985. Le moment Guizot. Paris: Gallimard.

RÉMOND, R. 1982. Les droites en france. Paris: Aubier.

ROMERO, J. L. 1978. Pensamiento conservador (1815-1898). Prólogo de José Luís Romero. Caracas: Biblioteca Ayacucho.

ROUSSEAU, J.-J. 1982. Considerações sobre o governo da Polônia e sua reforma projetada. Tradução de Luiz Roberto Salinas Fortes. São Paulo: Brasiliense.

1997. Do contrato social. Tradução de Lourdes Santos Machado. São Paulo: Nova Cultural.

SAFFORD, F. 2001. "Política, ideologia e sociedade na América Espanhola do pós-independência". In: BETHELL, L. (org.). História da América Latina. Vol. III: Da Independência a 1870. Tradução de Maria Clara Cescato. São Paulo: Edusp.

TORGAL, L. R. 1998. "O tradicionalismo absolutista e contra-revolucionário”. In: MATOSO, J. (dir.). História de Portugal: o liberalismo. Lisboa: Editorial Estampa.

VALDÈS, E. D. 2000. El pensamiento latinoamericano en el siglo xx - Entre la modernización y la identidad. Buenos Aires: Centro de Investigaciones Diego Barros Arana.

WARESQUIEL, E.; YVERT, B. 2002. Histoire de la restauration, 1814-1830: naissance de la France moderne. Paris: Editions Perrin. 


\section{O PENSAMENTO CONSERVADOR IBERO-AMERICANO NA ERA DAS INDEPENDÊNCIAS (1808-1850).}

CHRISTIAN EDWARD CYRIL LYNCH

A intenção do artigo é fornecer um panorama ideológico da América Ibérica da época das independências, especialmente no que diz respeito às ideologias de direita. Busca-se, assim, definir o que seja conservadorismo, distinguindo-o do puro reacionarismo para, em seguida, comparar a orientação de José Bonifácio e de Marquês de Caravelas, no Brasil, com aquela desenvolvida por Bolívar, tendo em vista os dilemas do conservadorismo ibero-americano. A comparação esclarece as diferentes trajetórias da antiga América portuguesa e da antiga América hispânica, no decorrer do século XIX. 
Palavras-chave: América Ibérica; Conservadorismo; Direita; Independências.

\section{CONSERVATIVE IBERO-AMERICAN THOUGHT IN THE AGE OF INDEPENDENCES (1808-1850)}

This article intends to study the right-wing ideologies of Latin America during the first half of the nineteenth century. At first, it tries to define what conservatism is and to point out its differences from the rhetoric of reaction; later, the thought of José Bonifacio and the Marquis of Caravelas is compared to that of Simon Bolivar, underlying the dilemmas of Latin American conservatism. The comparison enlightens the different ways followed by the ancient Portuguese and Hispanic America after political independence.

Keywords: Latin America; Conservatisms; Right wing ideologies; Independences. 